\title{
Export of calcium carbonate corrosive waters from the East Siberian Sea
}

\author{
Leif G. Anderson ${ }^{1}$, Jörgen Ek ${ }^{2}$, Ylva Ericson ${ }^{3}$, Christoph Humborg ${ }^{2,4}$, Igor Semiletov ${ }^{5,6,7}$, Marcus Sundbom $^{2}$, and \\ Adam Ulfsbo ${ }^{1,8}$ \\ ${ }^{1}$ Department of Marine Sciences, University of Gothenburg, 41296 Gothenburg, Sweden \\ ${ }^{2}$ Baltic Sea Centre, Stockholm University, 10691 Stockholm, Sweden \\ ${ }^{3}$ The University Centre in Svalbard, Pb 156, 9171 Longyearbyen, Norway \\ ${ }^{4}$ Department of Environmental Science and Analytical Chemistry, Stockholm University, 10691 Stockholm, Sweden \\ ${ }^{5}$ International Arctic Research Center, University Alaska Fairbanks, Fairbanks, AK 99775, USA \\ ${ }^{6}$ Pacific Oceanological Institute, Russian Academy of Sciences Far Eastern Branch, Vladivostok 690041, Russia \\ ${ }^{7}$ The National Research Tomsk Polytechnic University, Tomsk, Russia \\ ${ }^{8}$ Division of Earth and Ocean Sciences, Nicholas School of the Environment, Duke University, Durham, NC 27704, USA
}

Correspondence to: Leif G. Anderson (leif.anderson@marine.gu.se)

Received: 7 November 2016 - Discussion started: 15 November 2016

Revised: 21 February 2017 - Accepted: 13 March 2017 - Published: 5 April 2017

\begin{abstract}
The Siberian shelf seas are areas of extensive biogeochemical transformation of organic matter, both of marine and terrestrial origin. This in combination with brine production from sea ice formation results in a cold bottom water of relative high salinity and partial pressure of carbon dioxide $\left(p \mathrm{CO}_{2}\right)$. Data from the SWERUS-C3 expedition compiled on the icebreaker Oden in July to September 2014 show the distribution of such waters at the outer shelf, as well as their export into the deep central Arctic basins. Very high $p \mathrm{CO}_{2}$ water, up to $\sim 1000 \mu \mathrm{atm}$, was observed associated with high nutrients and low oxygen concentrations. Consequently, this water had low saturation state with respect to calcium carbonate down to less than 0.8 for calcite and 0.5 for aragonite. Waters undersaturated in aragonite were also observed in the surface in waters at equilibrium with atmospheric $\mathrm{CO}_{2}$; however, at these conditions the cause of undersaturation was low salinity from river runoff and/or sea ice melt. The calcium carbonate corrosive water was observed all along the continental margin and well out into the deep Makarov and Canada basins at a depth from about $50 \mathrm{~m}$ depth in the west to about $150 \mathrm{~m}$ in the east. These waters of low aragonite saturation state are traced in historic data to the Canada Basin and in the waters flowing out of the Arctic Ocean north of Greenland and in the western Fram Strait,
\end{abstract}

thus potentially impacting the marine life in the North Atlantic Ocean.

\section{Introduction}

The decrease in $\mathrm{pH}$ in the ocean as a result of uptake of anthropogenic carbon dioxide $\left(\mathrm{CO}_{2}\right)$ from the atmosphere is noted ocean acidification (e.g. Doney et al., 2009). The change in $\mathrm{pH}$ caused by the increase in partial pressure of $\mathrm{CO}_{2}\left(p \mathrm{CO}_{2}\right)$ from about $280 \mu \mathrm{atm}$ in preindustrial times to about $400 \mu$ atm today is in the order of $0.1 \mathrm{pH}$ unit. A continued usage of fossil fuels at the present rate has been projected to lead to an atmospheric level of close to $1000 \mu \mathrm{atm}$ at the end of this century, resulting in a further decrease in $\mathrm{pH}$ by about 0.3 units in oceanic surface waters (e.g. Orr et al., 2005). Changes in $\mathrm{pH}$ of this range will likely impact the marine ecosystem as well as society (e.g. Gattuso et al., 2015).

Biogeochemical processes in the Arctic Ocean can have a much greater impact on ocean acidification than that of anthropogenic $\mathrm{CO}_{2}$ (Anderson et al., 2009, 2011). Investigation of the East Siberian shelf area illustrates the substantial impact of organic matter decay on lowering $\mathrm{pH}$ and thus also the calcium carbonate saturation state (Semiletov et al., 
2016). The corrosive shelf water spreads far out into the deep central Arctic Ocean at a depth centred around $150 \mathrm{~m}$ and potentially further into the North Atlantic Ocean (Azetsu-Scott et al., 2010). Here it can have negative effects on aragoniteshelled pelagic organisms like the pteropods (e.g. Comeau et al., 2010), which are important in the Arctic Ocean and North Atlantic food web.

The Arctic Ocean is one of the oceans that experience the lowest natural $\mathrm{pH}$, a result of the high gas solubility in cold waters. On the other hand, the change in $\mathrm{pH}$ for a given increase in $p \mathrm{CO}_{2}$ is less in cold waters than in warm, as the buffer capacity for $\mathrm{CO}_{2}$ is less. However, there are several other processes than air-sea exchange of $\mathrm{CO}_{2}$ that impact $\mathrm{pH}$ of Arctic waters. Some Arctic shelf seas, such as the Chukchi Sea and the Barents Sea, are among the most productive of the world oceans and as such experience large natural seasonal variability in $p \mathrm{CO}_{2}$ and $\mathrm{pH}$. One consequence of the high primary productivity is low $p \mathrm{CO}_{2}$ in the inflow shelf seas (Carmack and Wassmann, 2006; Pipko et al., 2002) is that the surface waters of the central Arctic Ocean are largely undersaturated in $\mathrm{CO}_{2}$ (Jutterström and Anderson, 2010). This is a result of the waters being covered by sea ice that hampers air-sea flux, before the atmospheric exchange compensates for the $\mathrm{CO}_{2}$ taken up by the phytoplankton. Decreased summer sea ice cover in the central Arctic Ocean will likely reduce this effect and adjust the surface water closer to atmospheric equilibrium.

Increased $p \mathrm{CO}_{2}$ levels decrease carbonate ion $\left(\mathrm{CO}_{3}^{2-}\right)$ concentrations, which also reduces the solubility of calcium carbonate crystals, illustrated by the reaction

$\mathrm{CaCO}_{3}(\mathrm{~s}) \leftrightarrows \mathrm{Ca}^{2+}+\mathrm{CO}_{3}^{2-}$

where the solubility is determined by the chemical solubility product, $K_{\mathrm{so}}$, which is the product of the calcium and carbonate ion concentrations at chemical equilibrium, i.e. $K_{\text {so }}=\left[\mathrm{Ca}^{2+}\right]^{\text {equilibrium }} \times\left[\mathrm{CO}_{3}^{2-}\right]^{\text {equilibrium }}$. In the ocean $K_{\text {so }}$ is dependent on temperature, salinity and pressure. To determine whether the conditions are such that the water is supersaturated or undersaturated with respect to calcium carbonate, one often uses the saturation state, $\Omega$.

$\Omega=\frac{\left[\mathrm{Ca}^{2+}\right]^{\text {observed }} \times\left[\mathrm{CO}_{3}^{2-}\right]^{\text {observed }}}{K_{\text {so }}}$

Hence, if $\Omega$ is less than 1 the water is undersaturated, and if greater than 1 it is supersaturated.

Calcium carbonate crystals can have different structures, each with a specific $K_{\mathrm{so}}$. The most common are calcite and aragonite, but in cold environments like sea ice ikaite can also form (e.g. Dieckmann et al., 2008). Calcite and aragonite are mainly formed by biological calcification, where calcium carbonate is produced as part of an organism's structure. Even if the crystals are built up of carbonate ions it is in most cases hydrogen carbonate ions $\left(\mathrm{HCO}_{3}^{-}\right)$that are extracted by the organisms from seawater and converted to
$\mathrm{CO}_{3}^{2-}$ internally (e.g. Findlay et al., 2011). Thus, there might not be a direct coupling between the biological formation rate of $\mathrm{CaCO}_{3}$ minerals and ocean acidification. Instead it has been suggested that it is the ratio of $\mathrm{HCO}_{3}^{-}$to $\mathrm{H}^{+}$that controls the biotic $\mathrm{CaCO}_{3}$ precipitation (Bach, 2015), or more directly the increase in $\mathrm{H}^{+}$(Cyronak et al., 2016). However, the opposite reaction, i.e. dissolution of $\mathrm{CaCO}_{3}$ minerals, is influenced by ocean acidification through the chemical solubility product, at least as long as the crystals are directly exposed to seawater.

Among the biologically produced calcium carbonates, aragonite is more soluble than calcite, making the former more sensitive to ocean acidification. During biological formation of calcite, magnesium can be incorporated instead of calcium, which increases the solubility; the higher the content of magnesium, the higher the solubility (e.g. Haese et al., 2014). High-magnesium calcite has a higher solubility than aragonite, making this the most sensitive form. A range of these mineral forms are produced by organisms living in the Arctic Ocean. Among those producing aragonite skeletons are cold-water corals and pteropods, while most benthic organisms tend to produce a larger fraction of calcite. Consequently, there is a substantial diversity in the biological produced $\mathrm{CaCO}_{3}$ minerals and thus also different sensitivities to ocean acidification.

The very large shelf areas north of Siberia are heavily impacted by river input, adding fresh water and chemical constituents. The direct addition of high $p \mathrm{CO}_{2}$ runoff together with biochemical processes such as primary production and decay of organic matter, of both marine and terrestrial origin, strongly impact the calcium carbonate saturation state. The distribution of this specific water characteristic on the shelf as well as its export into, and circulation within, the deep basins is determined by the atmospheric pressure field that drives the oceanic currents (e.g. Jahn et al., 2010; Pipko et al., 2011).

In this contribution we show the importance of the Siberian shelves in producing calcium carbonate undersaturated waters that spread out into the deep Arctic Ocean and further towards the Atlantic Ocean. The processes behind the under-saturation are elucidated as well as the flow path of this signature in the Arctic Ocean.

\section{Methods}

This contribution is based on data that were collected during the SWERUS-C3 (Swedish-Russian-US Arctic Ocean Investigation of Climate-Cryosphere-Carbon Interactions) expedition with the Swedish icebreaker Oden along the outer Siberian shelf and covers a longitudinal range between about $125^{\circ} \mathrm{E}$ and $175^{\circ} \mathrm{W}$ (see Fig. 1 for station positions). Sampling was intensified across the shelf break along sections (A-F). Furthermore, historic data are used to evaluate how the waters from the Siberian shelf are spread out in the cen- 
(a)

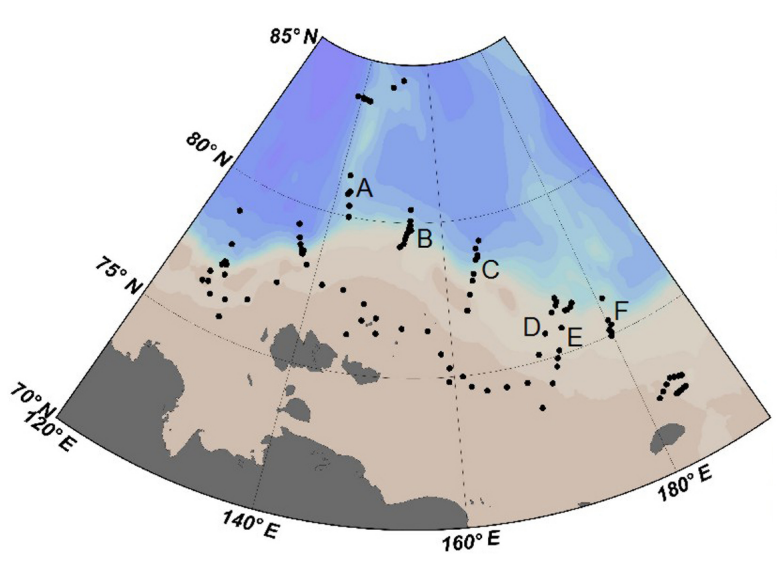

(b)

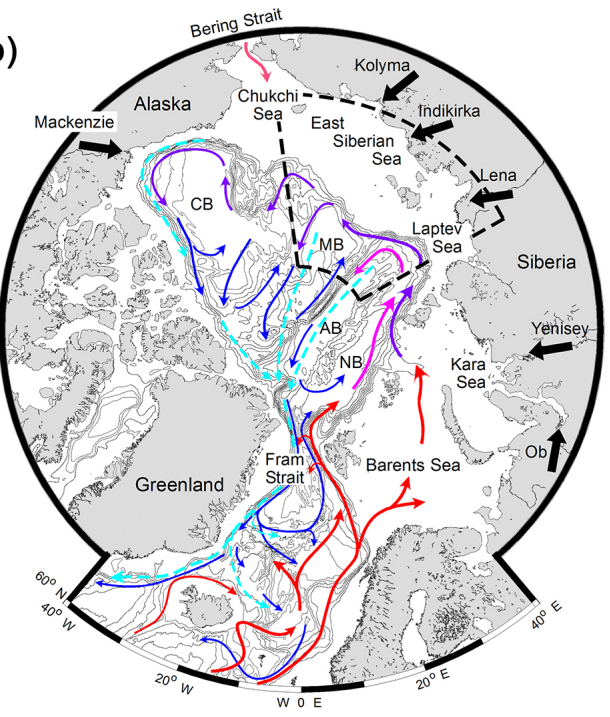

Figure 1. Map illustrating the station locations, with (a) sections noted and (b) general water mass circulation in the deep Arctic Ocean and its connection to surrounding oceans. The location of map in (a) is shown by the dotted insert in map (b).

tral Arctic Ocean and further towards Fram Strait on their way to the North Atlantic Ocean. These include data from north of Greenland collected during the Oden 1991 cruise (Anderson et al., 1994), data from the northern Fram strait collected in 2002 (Jutterström et al., 2008), and data from the Canada Basin collected in 2005 (Jones et al., 2008a).

The SWERUS-C3 data were gathered at about 100 stations, occupied between 15 July and 25 September 2014. Water samples were collected using a rosette system equipped with 24 bottles of Niskin type, each having a volume of $7 \mathrm{~L}$. The bottles were closed during the return of the CTD-rosette package from the bottom to the surface and water samples for all constituents were drawn soon after the rosette was secured in the CTD container.

The following constituents are used: dissolved inorganic carbon (DIC) (only stations visited after 24 August), total alkalinity (TA), pH, oxygen, nutrients, and bottle salinity. The order of sampling was determined by the risk of contamination, meaning that oxygen samples were collected first followed by the carbonate system parameters, the nutrients, and salinity. Water samples for salinity were analysed for more than $90 \%$ of the depths and when no data were available the CTD salinity was used. Temperature data were taken from the CTD.

Salinity and temperature data were collected using a SeaBird 911+ CTD with dual Sea-Bird temperature (SBE 3), conductivity (SBE 04C) and oxygen sensors (SBE 43) attached to the rosette system. Salinity was calibrated against deep water samples analysed on board using an AUTOSAL 8400B lab salinometer. The salinometer was calibrated using one standard sea water ampoule (IAPSO standard sea water, OSIL Environmental Instruments and Systems) before each batch of 24 samples. The accuracies of the Autosal salini- ties and CTD salinities were both within \pm 0.003 psu and the accuracy for temperature was $\pm 0.002^{\circ} \mathrm{C}$.

DIC was determined by a coulometric titration method based on Johnson et al. (1987), having a precision of $2 \mu \mathrm{mol} \mathrm{kg}{ }^{-1}$, estimated from duplicates, with the accuracy set by calibration against certified reference materials (CRM), supplied by A. Dickson, Scripps Institution of Oceanography (USA). TA was determined by automated open-cell potentiometric titration (Haraldsson et al., 1997), precision better than $2 \mu \mathrm{mol} \mathrm{kg}^{-1}$, with the accuracy set the same way as for DIC. Seawater $\mathrm{pH}$ was determined by a spectrophotometric method, based on the absorption ratio of the sulfonephtalein dye, $m$-cresol purple (mCP) (Clayton and Byrne, 1993). Purified mCP (Liu et al., 2011) was purchased from the laboratory of Robert H. Byrne, University of South Florida, USA. The accuracy was estimated to 0.006 from internal consistency calculations of analysed CRM samples and the precision, defined as the absolute mean difference of duplicate samples, was $\sim 0.001 \mathrm{pH}$ units.

Oxygen was measured by an automated Winkler titration system giving a precision of $\sim 1 \mu \mathrm{mol} \mathrm{kg}{ }^{-1}$. The accuracy was set by titrating known amounts of $\mathrm{KIO}_{3}$ salts that were dissolved in sulfuric acid. As the amount was known to better than $0.1 \%$ the accuracy should be significantly better than the precision. The deviation from saturation concentration was computed as apparent oxygen utilization (AOU) as $\left[\mathrm{O}_{2}\right]^{\mathrm{sat}}-\left[\mathrm{O}_{2}\right]^{\text {measured }}$.

Dissolved inorganic nitrogen species $\left(\mathrm{NH}_{4}, \mathrm{NO}_{2}+\mathrm{NO}_{3}\right)$, orthophosphate $\left(\mathrm{PO}_{4}\right)$ and dissolved silicate were measured on board using a four-channel continuous flow analyser (QuAAtro system, SEAL Analytical). Within each analysis run a calibration was done using standard solutions of $\mathrm{NH}_{4} \mathrm{Cl}, \mathrm{KNO}_{3}, \mathrm{~K}_{2} \mathrm{HPO}_{4}$ and a commercial stable silica- 

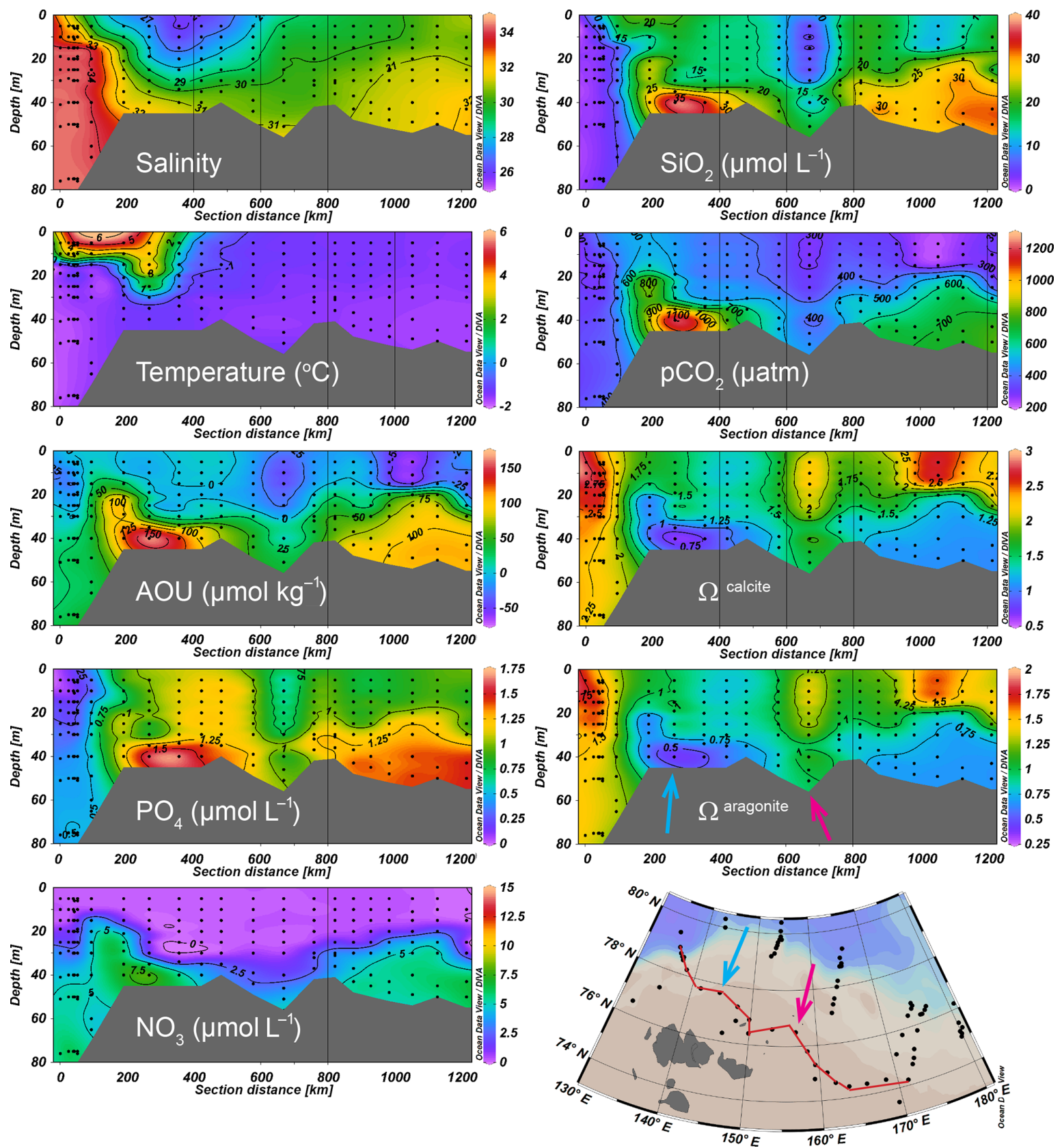

Figure 2. Sections along the outer East Siberian continental shelf as shown by the red line of the map. The location of the minimum in saturation state of calcium carbonate is noted by the blue arrow and the local maximum by the purple arrow.

compound solution. Analysis quality was further assured by automatic drift control using standard solutions and including CRM solutions prepared from commercial ampoules (QC RW1, batch VKI-9-3-0702) in the analysis run. Accuracy expressed as the median deviation of the measurements from the CRM solution for $\mathrm{NH}_{4}, \mathrm{NO}_{2}+\mathrm{NO}_{3}$ and $\mathrm{PO}_{4}$ was -0.15 , -0.11 , and $-0.018 \mu \mathrm{mol} \mathrm{L}^{-1}$, respectively. The CRM is not certified for silicate. The precision was, based on 28 determinations of standards, 3.7, 1.2, 2.7 and $1.3 \%$ for $\mathrm{NH}_{4}$, $\mathrm{NO}_{2}+\mathrm{NO}_{3}, \mathrm{PO}_{4}$ and $\mathrm{SiO}_{4}$, respectively.
The saturation states of the two major forms of calcium carbonate ( $\Omega^{\text {aragonite }}$ and $\Omega^{\text {calcite }}$ ) and $p \mathrm{CO}_{2}$ were calculated from the combination of $\mathrm{pH}$ and TA, as well as $\mathrm{pH}$ and DIC when the latter was available, using CO2SYS (van Heuven et al., 2011) with the carbonate dissociation constants $\left(\mathrm{K}_{1}\right.$ and $\mathrm{K}_{2}$ ) of Lueker et al. (2000), the solubility product, $K_{\text {so }}$ according to Mucci (1983) and the salinity-calcium ion concentration ratio of Riley and Tongudai (1967). When two computations were performed the reported values are the average of the two calculated for each sample. Input data in- 

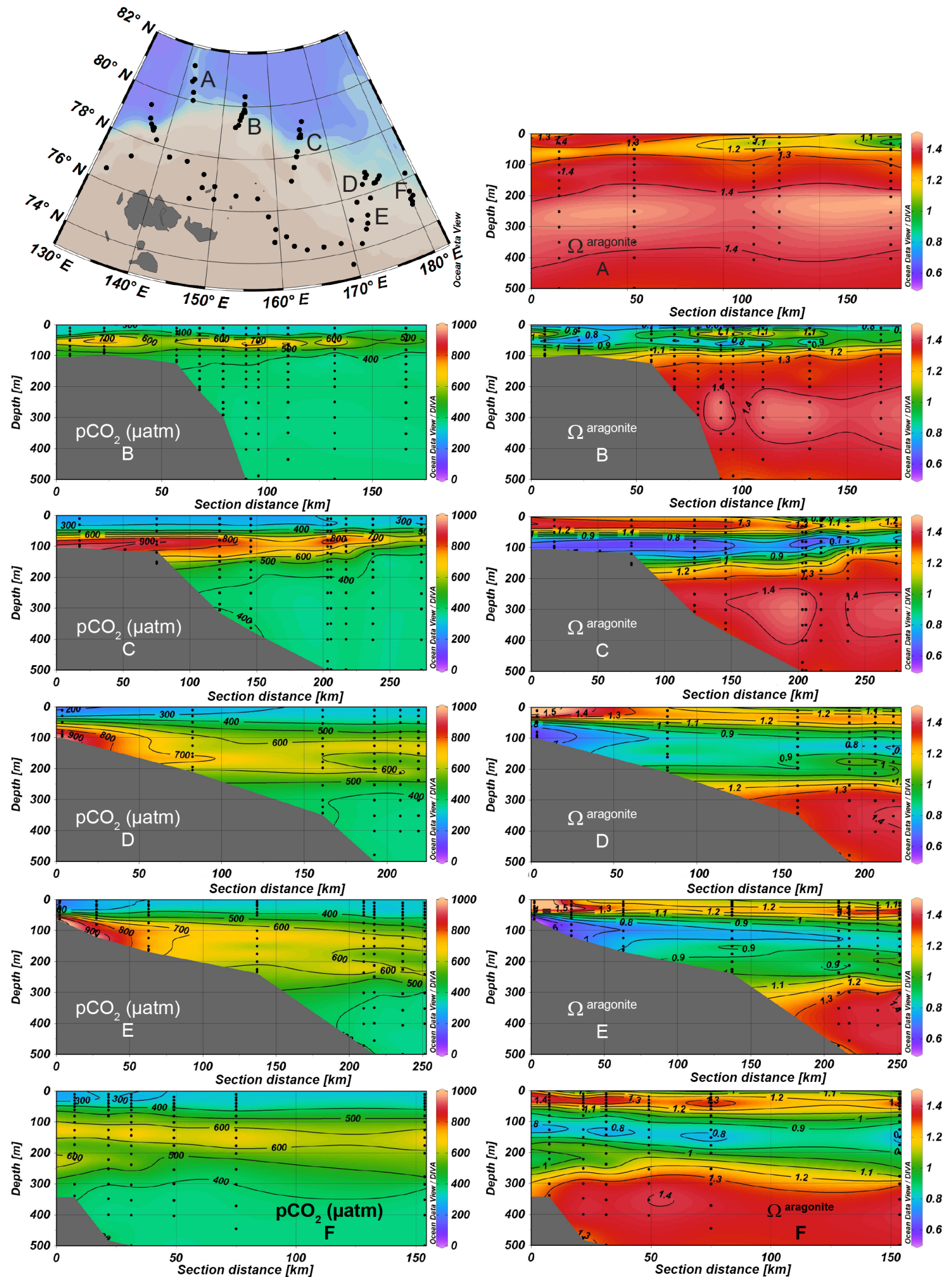

Figure 3. Sections A to $\mathrm{F}$ across the East Siberian shelf break, partial pressure of carbon dioxide $\left(p \mathrm{CO}_{2}\right)$ to the left and saturation state of aragonite $\left(\Omega^{\text {aragonite}}\right)$ to the right. On all sections the colour scale is from 0 to $1000 \mu$ atm for $p \mathrm{CO}_{2}$ and 0.5 to 1.5 for $\Omega^{\text {aragonite }}$. Note the variable horizontal extent of the different sections. The locations of the sections are noted on the inserted map. 
(a)
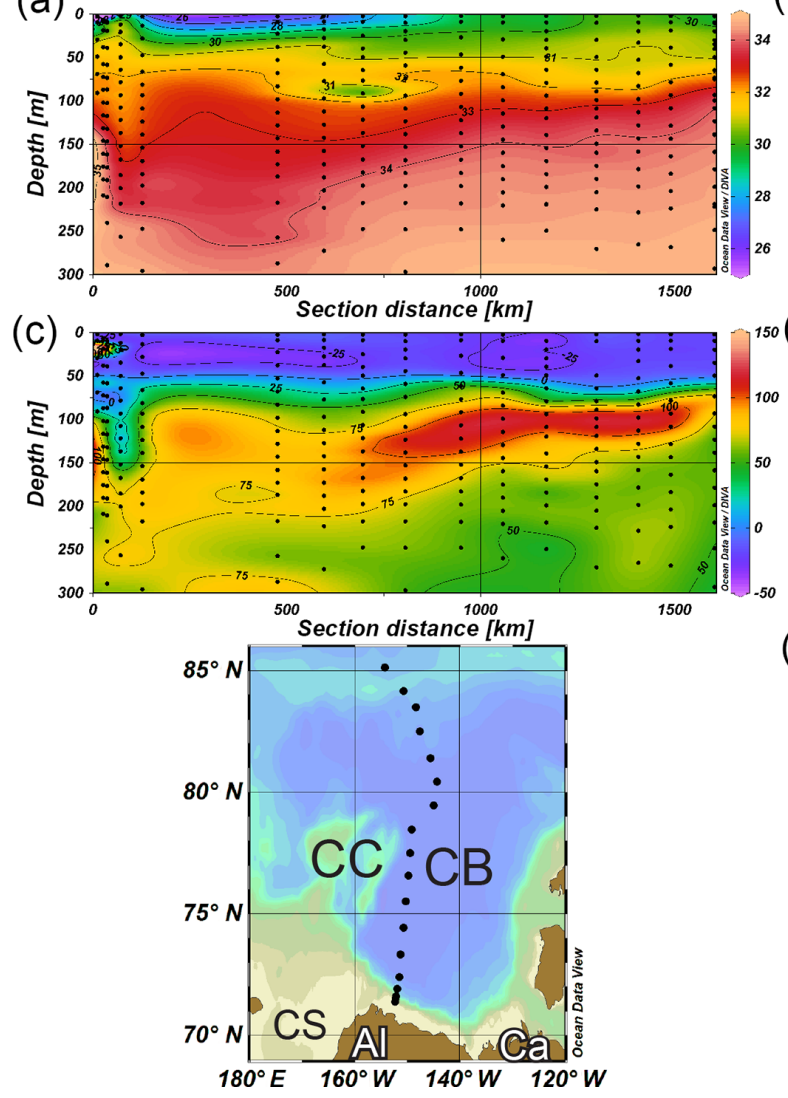

(b)
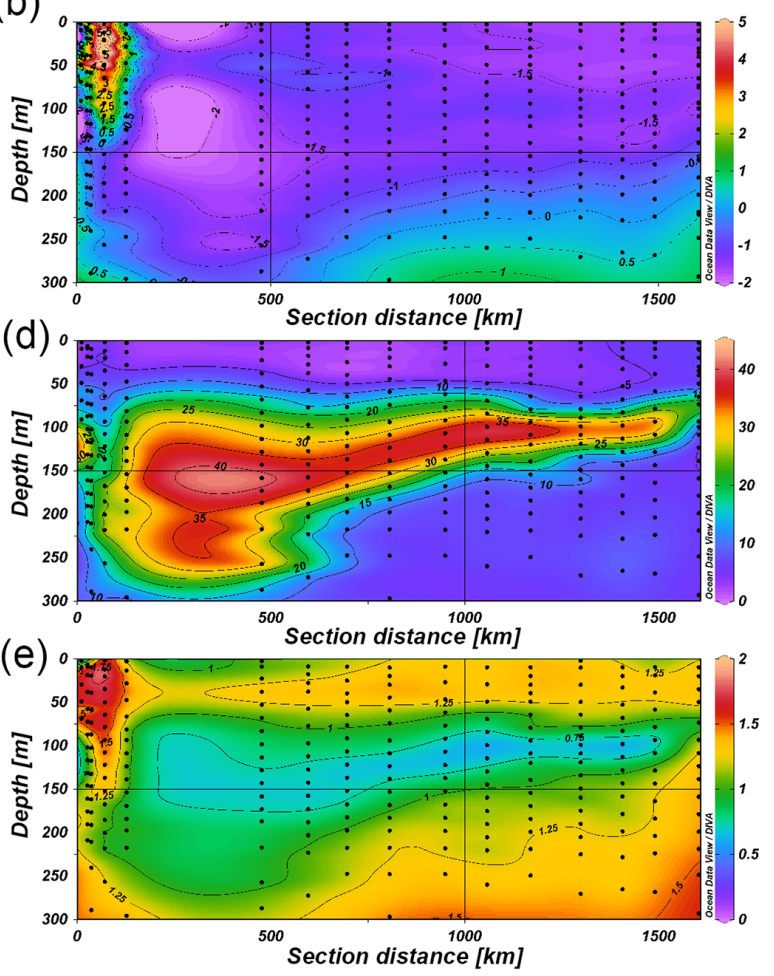

Figure 4. Sections of (a) salinity, (b) temperature, (c) AOU, (d) silicate, and (e) $\Omega^{\text {aragonite }}$ in the top $300 \mathrm{~m}$ across the Canada Basin as observed during the Beringia 2005 expedition. Station positions are noted on the map, with the abbreviations being CB, Canadian Basin; CC, Chukchi Cape; CS, Chukchi Sea; Al, Alaska; and Ca, Canada.

cluded salinity, temperature, $\mathrm{PO}_{4}$ and $\mathrm{SiO}_{4}$ data. The uncertainty was computed using a Monte Carlo approach (Legge et al., 2015) and expressed as double standard deviation, and it was about $2.5 \%$ for $p \mathrm{CO}_{2}$ and less than $1 \%$ for $\Omega$.

Furthermore, as the carbonate system was overdetermined the internal consistency (or thermodynamic consistency) was assessed by comparing measured values to calculated values (from any two of the three determined parameters DIC, TA and $\mathrm{pH}$ ) using the same CO2SYS MATLAB program (Van Heuven et al., 2011). The average mean differences between measured and calculated values were evaluated for $\mathrm{pH}$ to about 0.02 and for TA and DIC to about $7 \mu \mathrm{mol} \mathrm{kg} \mathrm{kg}^{-1}$ for each.

\section{Results}

Water undersaturated with respect to calcium carbonate was observed along the bottom of the shelf at most stations (Fig. 2), associated with high nutrient and low oxygen concentrations. The strongest signal was north of the New Siberian Islands, a local minimum in saturation state at about $157^{\circ} \mathrm{E}$ followed by a less strong signal further to the east.
Low saturation state with under-saturation in aragonite was also observed in the surface water north of the New Siberian Islands. This water had low salinity, high phosphate, and high silicate concentrations and relatively high $p \mathrm{CO}_{2}$ despite having nitrate concentrations as low as about $0.2 \mu \mathrm{mol} \mathrm{L}^{-1}$.

The extension of this high $p \mathrm{CO}_{2}$ and low $\Omega^{\text {aragonite }}$ water out into the deep basin was seen in a layer centred at about $100 \mathrm{~m}$ depth all along the shelf break from the east of the Lomonosov Ridge to $180^{\circ} \mathrm{E}$ (Fig. 3). Over the Lomonosov Ridge (section A) there was a faint minimum in $\Omega^{\text {aragonite }}$ even if the waters were never undersaturated. Moving east to section $\mathrm{B}$ undersaturated waters were observed both in the surface and at approximately $50 \mathrm{~m}$ depth. Further to the east, sections $\mathrm{C}, \mathrm{D}$ and $\mathrm{E}$ have strong $\Omega^{\text {aragonite }}$ minima centred at $\sim 100 \mathrm{~m}$ depth. In the most eastern section of this study, section $\mathrm{F}$, the minimum was less intense and was also found at somewhat greater depth, $\sim 150 \mathrm{~m}$. In all sections the minimum in $\Omega^{\text {aragonite }}$ was closely followed by a maximum in $p \mathrm{CO}_{2}$ (Fig. 3). In section $\mathrm{C}$ and even more so in $\mathrm{D}$ and $\mathrm{E}$ the $\Omega^{\text {aragonite }}$ minima were observed in close vicinity to the sediment. 


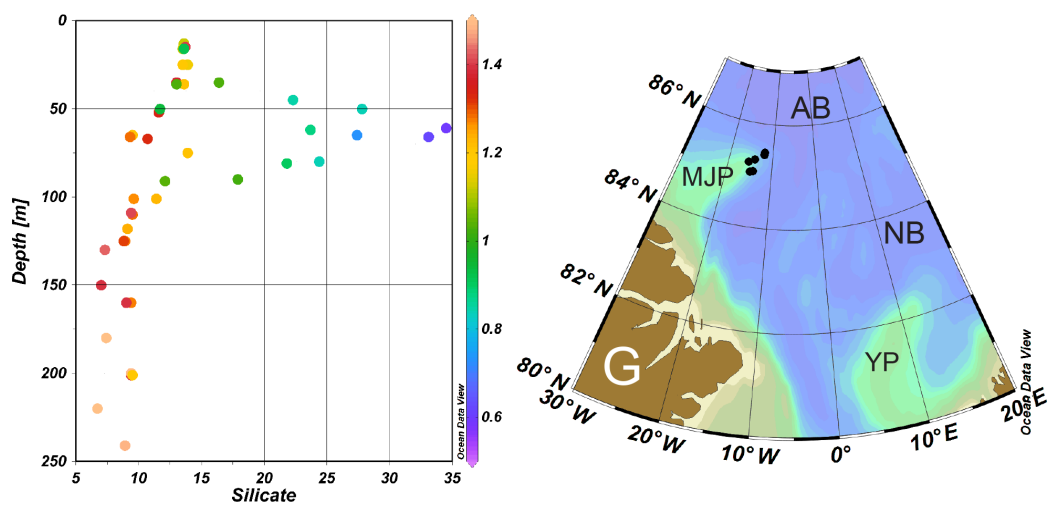

Figure 5. Silicate profiles of six stations over the Morris Jesup Plateau (MJP), colour-coded by $\Omega^{\text {aragonite }}$, as observed during the Oden 91 cruise. Station positions are noted on the map, with the abbreviations being AB, Amundsen Basin; NB, Nansen Basin; YP, Yermak Plateau; and $\mathrm{G}$, Greenland.

This low saturated water has been observed in the Canada Basin on several occasions (e.g. Yamamoto-Kawai et al., 2009; Anderson et al., 2010). During the Beringia 2005 expedition, where $\Omega^{\text {aragonite }}$ levels as low as 0.6 were observed at $100 \mathrm{~m}$ depth (Fig. 4), the layer of under-saturation was between 50 and $100 \mathrm{~m}$ thick and had the upper limit at about $75 \mathrm{~m}$ depth. It also had the typical signature of low oxygen and high nutrient concentrations from decay of organic matter. Water with high silicate and undersaturated in aragonite was observed at the tip of the Morris Jesup Plateau in 1991 (Fig. 5), where the subsurface waters from the Canadian Basin follow the continental margin towards the Fram Strait (Rudels et al., 1994). Water of similar signature, but less pronounced, was also seen at a depth of $50-75 \mathrm{~m}$ in the northwestern Fram Strait in May 2002, while the overlying low-salinity surface water was well above saturation with respect to calcium carbonate (Fig. 6). A distinct maximum in silicate was present at the Greenland continental margin and centred around a salinity of 33. It was associated with a minimum in $\mathrm{pH}$ and thus also in $\Omega^{\text {aragonite }}$, but with a less pronounced oxygen minimum (AOU maximum).

\section{Discussion}

The two major factors that impact calcium carbonate solubility in the surface ocean are salinity and $\mathrm{pH}$, where the former affects the calcium ion and DIC concentrations and the latter controls the relative distribution of the inorganic carbon speciation. In the open ocean the latter is mainly determined by $\mathrm{CO}_{2}$, either controlled by exchange with the atmosphere or through primary production/decay of organic matter. The concentrations of nutrients and AOU are high close to the bottom at most stations occupied on the shelf (Fig. 2), showing the importance of organic matter decay in controlling the chemical signature of the Siberian shelf bottom waters. Low $\Omega^{\text {aragonite }}$ and $\Omega^{\text {calcite }}$ values are associated with high $p \mathrm{CO}_{2}$ (low $\mathrm{pH}$ ) and high nutrient concentrations as well as low oxy- gen (high AOU). The corrosive water extending out into the deep basin is strongly associated with high $p \mathrm{CO}_{2}$ (Fig. 3) and high nutrients, further illustrating that decay of organic matter also here is the cause of this signature.

However, mixing with low-salinity water also has an impact, especially on the shelf where the influence from river discharge is stronger and melting sea ice occurs that add to lowering salinity. As illustrated in Fig. 7a aragonite undersaturation is found in most surface waters of salinity $<28$, waters that are found north of the New Siberian Islands (Fig. 2). In this region the surface water (top $10 \mathrm{~m}$ ) nitrate concentration is very low, averaging $0.25 \pm 0.05 \mu \mathrm{mol} \mathrm{L}^{-1}$, illustrating that phytoplankton blooms are well advanced and that nitrate is the limiting nutrient as the phosphate concentration is high, averaging $1.1 \pm 0.1 \mu \mathrm{mol} \mathrm{L}{ }^{-1}$ (Fig. 2). Despite these signatures of primary production, $\mathrm{CO}_{2}$ is slightly supersaturated, averaging $420 \pm 30 \mu \mathrm{atm}$ and oxygen is close to equilibrium, averaging $100 \pm 1 \%$, i.e. $\mathrm{AOU}$ is around zero. Hence the rate of $\mathrm{CO}_{2}$ consumption by primary production is exceeded by respiration of organic matter low in nutrient content, and this is likely of terrestrial origin (Anderson et al., 2009). $\mathrm{CO}_{2}$ can also be produced by photo degradation of dissolved organic matter (e.g. Cory et al., 2015), at least if the water is not too turbid. However, our data cannot assess the relative roles of these two processes.

The very high silicate concentrations indicate that mainly river runoff and not sea-ice melt is the source of freshwater to low-salinity waters. Consequently, this region is most likely heavily impacted by the plume of the large Siberian rivers, here dominated by the Lena River. The fact that $\mathrm{CO}_{2}$ is supersaturated strongly indicates that the river runoff not only lowers the calcium and carbonate concentrations by dilution but also decreases $\mathrm{pH}$ by addition of $\mathrm{CO}_{2}$. This could be either from high $p \mathrm{CO}_{2}$ in the river water itself or from decay of organic carbon that is added by the river runoff. Considering a freshwater residence time on the Laptev shelf of several years (Schlosser et al., 1994), the latter is the most plausi- 

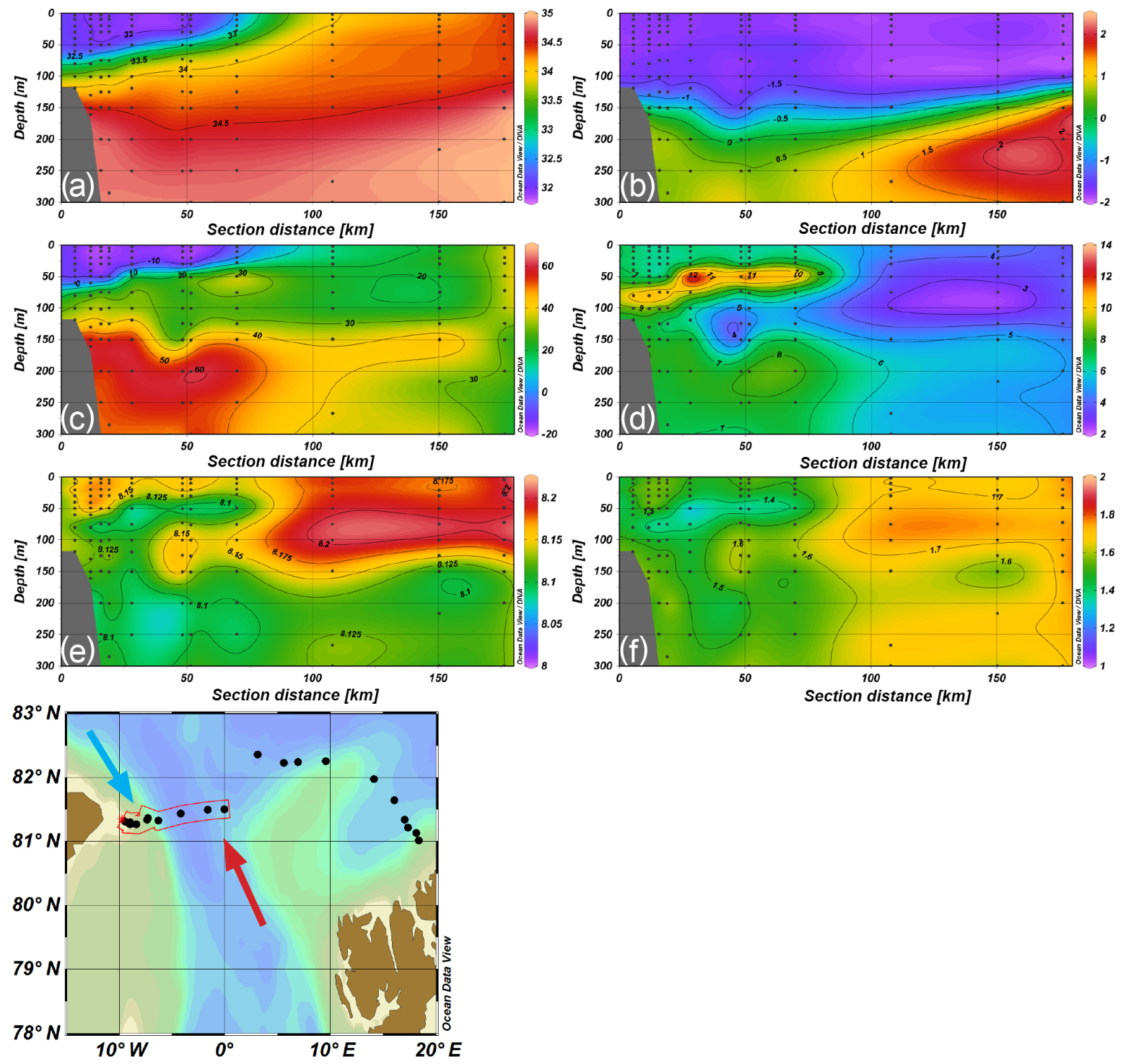

Figure 6. Sections of (a) salinity, (b) temperature, (c) $\mathrm{AOU}$, (d) $\mathrm{SiO}_{2}$, (e) $\mathrm{pH}_{\mathrm{in} \text { situ }}^{\text {tot }}$, and (f) $\Omega^{\text {aragonite }}$, across the northern Fram Strait at about $81.5^{\circ} \mathrm{N}$ from the Yermak Plateau to Greenland as noted on the map, collected in May 2002. The arrows illustrate the north-flowing warm Atlantic and the south-flowing cold Arctic surface waters.

ble explanation as $\mathrm{CO}_{2}$ from the runoff would have time to largely equilibrate during the transit to the area of observation. This is supported by reconstructed velocity fields (using a 4-D variational approach) and trajectories of passive tracers launched in the East Siberian Arctic Shelf, which show that during 2 years the surface water mass approaches the area near the North Pole (Shakhova et al., 2015).

Summer water $p \mathrm{CO}_{2}$ values of the central Arctic Ocean has normally been observed to be well below atmospheric levels (e.g. Jutterström and Anderson, 2010; Ulfsbo et al., 2014), but during the Russian North Pole-33 drifting station $\mathrm{CO}_{2}$ supersaturation of up to $100 \mu$ atm was observed over the Amundsen Basin at about $86^{\circ} \mathrm{N}$ (Semiletov et al., 2007). This is the region where the Lena River plume typi- cally passes (e.g. Anderson et al., 2004) and these high $p \mathrm{CO}_{2}$ values can thus be an indication of a direct contribution from the Lena River plume, mineralization of terrestrial DOC following the river plume, rapid turnover of sub-ice dissolved organic matter which is closely connected with high sea-ice production, or any combination of these sources (Semiletov et al., 2007). A time lag of 4-6 years between the Lena River discharge anomalies, ice conditions in the Siberian seas, and ice export through Fram Strait was found with a correlation of $\sim 0.7$ (Semiletov et al., 2000). During this passage over the central Arctic Ocean the $p \mathrm{CO}_{2}$ levels decreases by outgassing, mixing of water masses as well as by primary production, resulting in that the surface water that flow out 

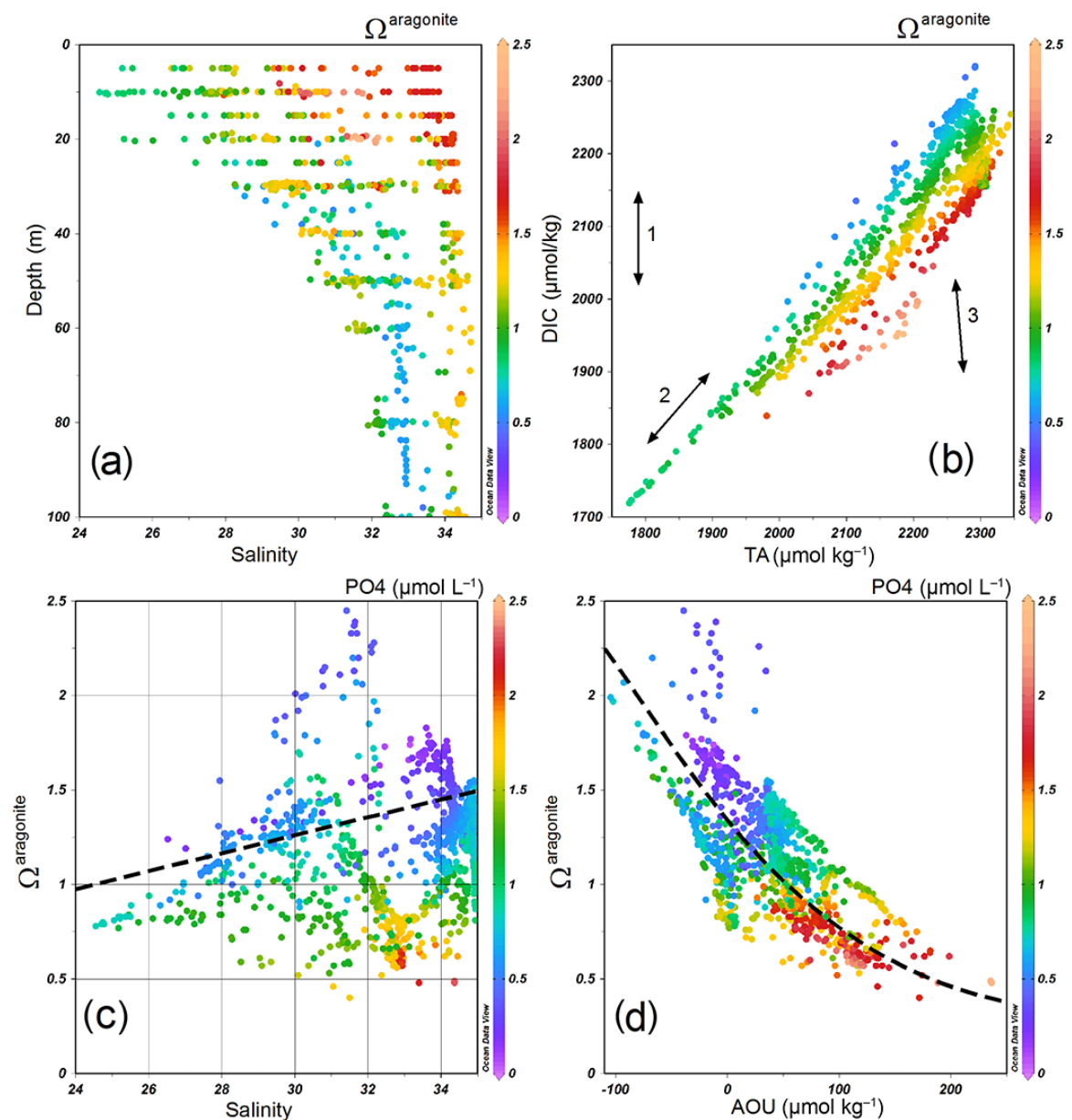

Figure 7. Plot of (a) salinity versus depth (b) DIC versus TA, both colour-coded by $\Omega^{\text {aragonite }}$, and (c) $\Omega^{\text {aragonite }}$ versus salinity and (d) $\Omega^{\text {aragonite }}$ versus AOU, both colour-coded by $\mathrm{PO}_{4}$. In (b) arrows are drawn where the slope are to illustrate the impact by air-sea $\mathrm{CO}_{2}$ gas exchange (1), dilution of water with zero DIC and TA (2) and primary production (down) and decay of organic matter (up) (3). The location and length of the arrows are arbitrary. In (c) a line is drawn that represents the dilution of Atlantic layer water with water of zero $S$, DIC and TA, and in (d) a line is drawn that represents a typical surface water that is impacted by primary production and decay of organic matter. Details of these lines are given in the text.

through Fram Strait in the East Greenland Current is supersaturated with respect to calcium carbonate (Fig. 6).

The dilution is not a dominating process of low $\Omega^{\text {aragonite }}$ throughout the water column in the study region as seen in a DIC-TA plot (Fig. 7b). The degree of saturation varies more with shifts in DIC by air-sea exchange (direction of arrow 1) and primary production/organic matter decay (direction of arrow 3 ) than dilution (direction of arrow 2), where the latter has an effect on both TA and DIC. No clear trend can be seen when $\Omega^{\text {aragonite }}$ is plotted as a function of salinity (Fig. 7c) and the data certainly do not follow the dilution line (representing dilution of Atlantic layer water having $S=34.85$, $T=-1{ }^{\circ} \mathrm{C}, \quad$ DIC $=2170 \mu \mathrm{mol} \mathrm{kg}-1, \quad \mathrm{TA}=2300 \mu \mathrm{mol} \mathrm{kg}-1$ with water of zero $S$, DIC and TA), even if there is less water supersaturated at the lower salinities. Rather, the low $\Omega^{\text {aragonite }}$ is associated with high $\mathrm{PO}_{4}$, implying organic matter decay as the main cause. This conclusion is strengthened

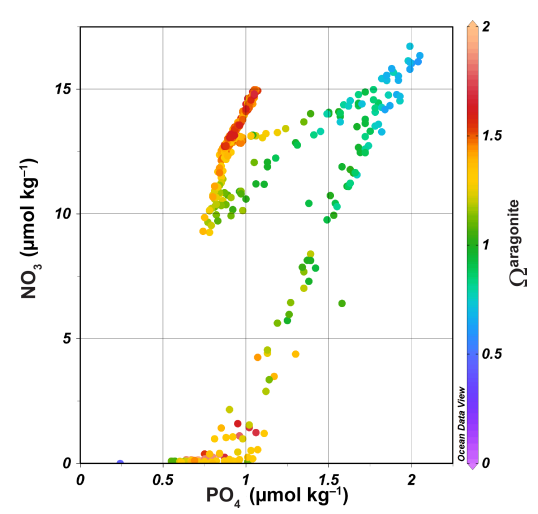

Figure 8. Nitrate versus phosphate as observed in the Canada Basin during the Beringia 2005 expedition (station locations same as in Fig. 4), colour-coded by $\Omega^{\text {aragonite }}$. 

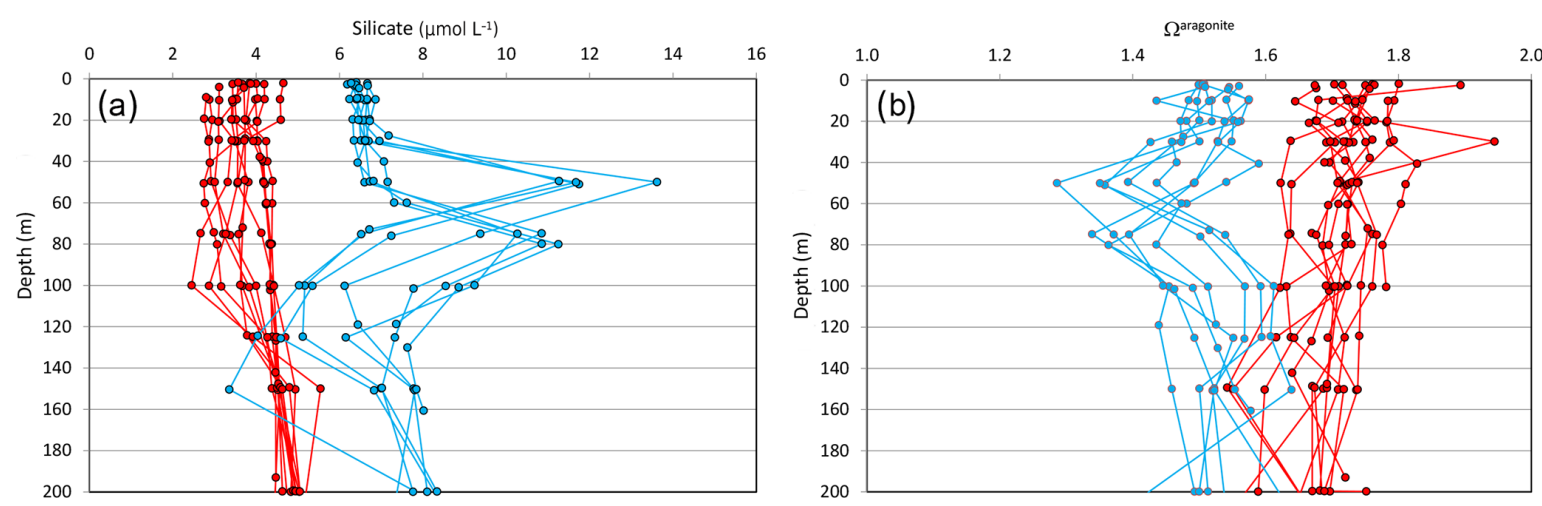

Figure 9. Depth profiles of silicate (a) and $\Omega^{\text {aragonite }}(\mathbf{b})$ in the Fram Strait around $82^{\circ} \mathrm{N}$ in 2002 . The $2002 \Omega^{\text {aragonite }}$ values are all computed from $\mathrm{pH}$ and TA and cover the whole strait. There is a distinct difference in both the silicate and $\Omega^{\text {aragonite }}$ properties in the north-flowing Atlantic water (red with a surface salinity around 34.5) and the south-flowing Arctic waters (blue with a surface salinity around 32). Both

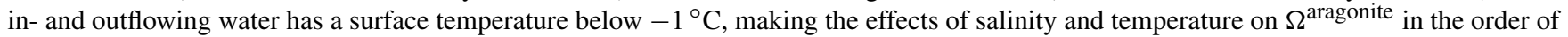
maximum 0.05 .

by the association between $\Omega^{\text {aragonite }}$ and AOU (Fig. 7d). A line is drawn that represents a typical surface water $(S=33$, $T=-1{ }^{\circ} \mathrm{C}, \quad \mathrm{PO}_{4}=1 \mu \mathrm{mol} \mathrm{L}{ }^{-1}, \quad \mathrm{NO}_{3}=16 \mu \mathrm{mol} \mathrm{L}^{-1}$, $\mathrm{AOU}=0, \quad \mathrm{DIC}=2046 \mu \mathrm{mol} \mathrm{kg}{ }^{-1}, \quad \mathrm{TA}=2169 \mu \mathrm{mol} \mathrm{kg}^{-1}$ ) that is impacted by primary production and decay of organic matter having the classical Redfield-Ketchum-Richards ratio of the elements $\mathrm{C}: \mathrm{N}: \mathrm{P}: \mathrm{O}_{2}=106: 1: 16:-138$ (Redfield et al., 1963). This computation is done assuming classical marine organic matter having this elemental composition. However, the correlation between $\Omega^{\text {aragonite }}$ and AOU will not be much impacted if instead terrestrial organic matter of lower nutrient content decays. Most of the data, in general, follow the shape of this line even if the spread is substantial. It should be noted that all data collected during the expedition are included, i.e. including water originating from both the Atlantic and the Pacific oceans with large variability in time since contact with the atmosphere. One example is the blue data that deviate from the line in the upper left of the graph, which likely is a result of photosynthesis in the surface water, where outgassing of oxygen to the atmosphere is faster than the uptake of $\mathrm{CO}_{2}$. These are surface waters of salinities around 32 (Fig. 7a and c).

The low $\Omega^{\text {aragonite }}$ water observed along the continental margin (Fig. 3) likely flows to the east and spreads out into the deep basin. In 2005 it was seen in the Canada Basin (Fig. 4) and likely confined to the Beaufort Gyre and hence its extension depends on the atmospheric pressure field (e.g. Proshutinsky et al., 2009; Carmack et al., 2016). Decadal variability in the fresh water content of the Beaufort Gyre experienced a significant change in the 1990s, forced by a change in the atmospheric circulation regime. For instance, in 1979 silicate concentrations as high as $40 \mu \mathrm{mol} \mathrm{L}^{-1}$ were observed over the Lomonosov ridge close to the North Pole during the LOREX ice camp (Moore et al., 1983), but in 1991 the silicate maximum was completely absent even in the Makarov Basin close to the North Pole (Anderson et al., 1994). One consequence of this variable extent of the Beaufort Gyre is that the export of the high-nutrient, low- $\Omega^{\text {aragonite }}$ water out into the North Atlantic Ocean is fluctuating with time.

Jones et al. (2003) identified Pacific-originating water by its excess phosphate concentration relative to nitrate and used the nitrate to phosphate relationship to trace it in the North Atlantic Ocean and found significant fractions in the Fram Strait, the Denmark Strait, and the Labrador Sea, but these were variable between different years. For many of the cruises discussed by Jones et al. (2003) there were no carbonate system data measured and hence $\Omega^{\text {aragonite }}$ could not be computed. However, it is evident that the aragonite undersaturated water is well confined to the water high in nutrients and with an excess of phosphate (Fig. 8), i.e. a property that was observed in parts of the North Atlantic by Jones et al. (2003). Hence, this undersaturated water is also likely exported well into the North Atlantic Ocean.

The 2002 observations show a minimum of less than 1.4 in aragonite saturation, but not undersaturated, in the northwestern Fram Strait (Fig. 6). This minimum is centred around a salinity of 33, but the computed fraction of Pacific water was about $2 \%$ with the major fraction of freshwater being river runoff (Jones et al., 2008b). Hence, the signature of calcium carbonate undersaturation was lessened from the source to the observation of this investigation, i.e. the East Siberian Arctic shelves, by water mass mixing.

However, when one compares the conditions of the waters flowing into the Arctic Ocean in the West Spitsbergen Current and the one flowing out in the East Greenland Current there are distinct differences (Fig. 9). The silicate concentration is at least $2 \mu \mathrm{mol} \mathrm{L}{ }^{-1}$ higher in the top $200 \mathrm{~m}$, while the $\Omega^{\text {aragonite }}$ values are in the order 0.2 lower in the top $100 \mathrm{~m}$. This is most likely a result of addition of freshwater by both river runoff and sea ice melt, but even more important is the 
decay of organic matter. The effect by freshening can decrease $\Omega^{\text {aragonite }}$ by no more than 0.05 under the conditions observed, pointing to the importance of organic matter decay during the circulation of these waters in the Arctic Ocean.

\section{Conclusions}

Corrosive surface water is exported to the central Arctic Ocean by the plumes of the large Siberian rivers, dominated by the Lena River in the Laptev-East Siberian seas region. This signature is maintained in the shelf by photo degradation (e.g. Cory et al., 2015) and/or microbial degradation of organic matter that to a large degree is of terrestrial origin (e.g. Alling et al., 2012; Tesi et al., 2014; Vonk et al., 2014). However, the signature of surface water undersaturated with respect to calcium carbonate does not spread far out into the deep central basins as mixing with surrounding water masses and outgassing of $\mathrm{CO}_{2}$ to the atmosphere increase the saturation state with time. Furthermore, the saturation state is also lowered by primary production in the surface waters when light and nutrients are available.

Highly calcium carbonate corrosive waters are produced along the bottoms of the East Siberian seas through degradation of organic matter. This water is exported into the deep Makarov and Canada basins at a depth range of about 50$150 \mathrm{~m}$. The signature of this subsurface water is maintained within the Beaufort Gyre and is exported out to the North Atlantic through eastern Fram Strait, and likely also through the Canadian Arctic Archipelago.

The salinity range of this water is $32-34$ and there is a potential for this water to be mixed up to layers inhabited by aragonite-forming organisms such as pteropods. Such mixing can be either a result of wind or through sea ice formation when the surface layer gets homogenized by brine release.

Data availability. Data are available upon request to the corresponding author.

Competing interests. The authors declare that they have no conflict of interest.

Acknowledgements. This research was supported by the Swedish Knut and Alice Wallenberg Foundation (KAW); the Swedish Research Council, VR (L.G.A. 621-2013-5105); the Swedish Research Council Formas (A.U. \#2014-1165); and the Russian Government (I.S. grant no. 14,Z50.31.0012/03.19.2014). We thank the supporting crew and captain of I/B Oden and are grateful for the support of the Swedish Polar Secretariat, as well as for the constructive comments by Johan Ingri and two anonymous reviewers on an earlier version of this paper.
Edited by: Ö. Gustafsson

Reviewed by: J. Ingri and two anonymous referees

\section{References}

Alling, V., Porcelli, D., Mörth, C.-M., Anderson, L. G., SanchezGarcia, L., Gustafsson, Ö., Andersson, P. S., and Humborg, C.: Degradation of terrestrial organic carbon, primary production and out-gassing of $\mathrm{CO}_{2}$ along the Laptev and East Siberian Seas as inferred from $\delta^{13} \mathrm{C}$ values of DIC, Geochim. Cosmochim. Ac., 95, 143-159, 2012.

Anderson, L. G., Björk, G., Holby, O., Kattner, G., Koltermann, P. K., Jones, E. P., Liljeblad, B., Lindegren, R., Rudels, B., and Swift, J.: Water Masses and Circulation in the Eurasian Basin: Results from the Oden 91 North Pole Expedition, J. Geophys. Res., 99, 3273-3283, 1994.

Anderson, L. G., Jutterström, S., Kaltin, S., Jones, E. P., and Björk, G.: Variability in river runoff distribution in the Eurasian Basin of the Arctic Ocean, J. Geophys. Res., 109, C01016, doi:10.1029/2003JC001773, 2004.

Anderson, L. G., Jutterström, S., Hjalmarsson, S., Wåhlström, I., and Semiletov, I. P.: Out-gassing of $\mathrm{CO}_{2}$ from Siberian Shelf Seas by terrestrial organic matter decomposition, Geophys. Res. Lett., 36, L20601, doi:10.1029/2009GL040046, 2009.

Anderson, L. G., Tanhua, T., Björk, G., Hjalmarsson, S., Jones, E. P., Jutterström, S., Rudels, B., Swift, J. H., and Wåhlström, I.: Arctic Ocean shelf - basin interaction, an active continental shelf $\mathrm{CO}_{2}$ pump and its impact on the degree of calcium carbonate dissolution, Deep-Sea Res. Pt. I, 57, 869-879 doi:10.1016/j.dsr.2010.03.012, 2010.

Anderson, L. G., Björk, G., Jutterström, S., Pipko, I., Shakhova, N., Semiletov, I., and Wåhlström, I.: East Siberian Sea, an Arctic region of very high biogeochemical activity, Biogeosciences, 8 , 1745-1754, doi:10.5194/bg-8-1745-2011, 2011.

Azetsu-Scott, K., Clarke, A., Falkner, K., Hamilton, J., Jones, E. P., Lee, C., Petrie, B., Prinsenberg, S., Starr, M., and Yeats, P.: Calcium carbonate saturation states in the waters of the Canadian Arctic Archipelago and the Labrador Sea, J. Geophys. Res., 115, C11021, doi:10.1029/2009JC005917, 2010.

Bach, L. T.: Reconsidering the role of carbonate ion concentration in calcification by marine organisms, Biogeosciences, 12, 49394951, doi:10.5194/bg-12-4939-2015, 2015.

Carmack, E. and Wassmann, P.: Food webs and physicalbiological coupling on pan-Arctic shelves: Unifying concepts and comprehensive perspectives, Prog. Oceanogr., 71, 446-477, doi:10.1016/j.pocean.2006.10.004, 2006.

Carmack, E. C., Yamamoto-Kawai, M., Haine, T. W. N., Bacon, S., Bluhm, B. A., Lique, C., Melling, H., Polyakov, I. V., Straneo, F., Timmermans, M.-L., and Williams, W. J.: Freshwater and its role in the Arctic Marine System: Sources, disposition, storage, export, and physical and biogeochemical consequences in the Arctic and global oceans, J. Geophys. Res.-Biogeo., 121, 675-717, doi:10.1002/2015JG003140, 2016.

Clayton, T. D. and Byrne, R. H.: Spectrophotometric seawater $\mathrm{pH}$ measurements: total hydrogen ion concentration scale calibration of m-cresol purple at-sea results, Deep-Sea Res. Pt. I, 40, 21152129, 1993. 
Comeau, S., Jeffree, R., Teyssié, J.-L., and Gattuso, J.-P.: Response of the Arctic pteropod Limacina helicina to projected future environmental conditions, PloS one, 5, e11362, doi:10.1371/journal.pone.0011362, 2010.

Cory, R. M., Harrold, K. H., Neilson, B. T., and Kling, G. W.: Controls on dissolved organic matter (DOM) degradation in a headwater stream: the influence of photochemical and hydrological conditions in determining light-limitation or substratelimitation of photo-degradation, Biogeosciences, 12, 6669-6685, doi:10.5194/bg-12-6669-2015, 2015.

Cyronak, T., Schultz, K. G., and Lokiel, P. L.: The Omega myth: what really drives lower calcification rates in an acidifying ocean, ICES J. Mar. Sci., 73, 558-562, 2016.

Dieckmann, G. S., Nehrke, G., Papadimitriou, S., Göttlicher, J., Steininger, R., Kennedy, H., Wolf-Gladrow, D., and Thomas, D. N.: Calcium carbonate as ikaite crystals in Antarctic sea ice, Geophys. Res. Lett., 35, L08501, doi:10.1029/2008GL033540, 2008.

Doney, S. C., Fabry, V. J., Feely, R. A., and Kleypas, J. A.: Ocean acidification: the other $\mathrm{CO}_{2}$ problem, Annu. Rev. Mar. Sci., 1, 169-192, doi:10.1146/annurev.marine.010908.163834, 2009.

Findlay, H. S., Wood, H. L., Kendall, M. A., Spicer, J. I., Twitchett, R. J., and Widdicombe, S.: Comparing the impact of high $\mathrm{CO}_{2}$ on calcium carbonate structures in different marine organisms, Mar. Biol. Res., 7, 565-575, 2011.

Gattuso, J.-P., Magnan, A., Billé, R., Cheung, W. W. L., Howes, E. L., Joos, F., Allemand, D., Bopp, L., Cooley, S. R., Eakin, C. M., Hoegh-Guldberg, O., Kelly, R. P., Pörtner, H.-O., Rogers, A. D., Baxter, J. M., Laffoley, D., Osborn, D., Rankovic, A., Rochette, J., Sumaila, U. R., Treye, S., and Turley C.: Contrasting futures for ocean and society from different anthropogenic $\mathrm{CO}_{2}$ emissions scenarios, Science, 349, 6243, doi:10.1126/science.aac4722, 2015.

Haese, R. R., Smith, J., Weber, R., and Trafford, J.: Highmagnesium calcite dissolution in tropical continental shelf sediments controlled by ocean acidification, Environ. Sci. Technol., 48, 8522-8528, 2014.

Haraldsson, C., Anderson, L. G., Hassellöv, M., and Hulth, S.: Rapid, high-precision potentiometric titration of alkalinity in ocean and sediment pore waters, Deep-Sea Res., 44, 2031-2044, 1997.

Jahn, A., Tremblay, B., Mysak, L. A., and Newton, R.: Effect of the large-scale atmospheric circulation on the variability of the Arctic Ocean freshwater export, Clim. Dynam. 34, 201-222, doi:10.1007/s00382-009-0558-z, 2010.

Johnson, K. M., Sieburth, J. M., Williams, P. J., and Brandström, L.: Coulometric total carbon dioxide analysis for marine studies: automation and calibration, Mar. Chem., 21, 117-133, 1987.

Jones, E. P., Swift, J. H., Anderson, L. G., Lipizer, M., Civitarese, G., Falkner, K., Kattner, G., and McLaughlin, F.: Tracing Pacific Water in the North Atlantic Ocean, J. Geophys. Res., 108, 3114, doi:10.1029/2001JC001141, 2003.

Jones, E. P., Anderson, L. G., Jutterström, S., Mintrop, L., and Swift, J. H.: Pacific freshwater, river water and sea ice meltwater across Arctic Ocean basins: Results from the 2005 Beringia Expedition, J. Geophys. Res., 113, C08012, doi:10.1029/2007JC004124, 2008a.

Jones, E. P., Anderson, L. G., Jutterström, S., and Swift, J. H.: Sources and Distribution of Fresh water in the
East Greenland Current, Prog. Oceanogr., 78, 37-44, doi:10.1016/j.pocean.2007.06.003, 2008b.

Jutterström, S. and Anderson, L. G.: Uptake of $\mathrm{CO}_{2}$ by the Arctic Ocean in a changing climate, Mar. Chem., 122, 96-104, doi:10.1016/j.marchem.2010.07.002, 2010.

Jutterström, S., Jeansson, E., Anderson, L. G., Bellerby, R., Jones, E. P., Smethie Jr., W. M., and Swift, J. H.: Evaluation of anthropogenic carbon in the Nordic Seas using observed relationships of N, P and C versus CFCs, Prog. Oceanogr., 78, 78-84, doi:10.1016/j.pocean.2007.06.001, 2008.

Legge, O. J., Bakker, D. C. E., Johnson, M. T., Meredith, M. P., Venables, H. J., Brown, P. J., and Lee, G. A.: The seasonal cycle of ocean-atmosphere $\mathrm{CO}_{2}$ flux in Ryder Bay, west Antarctic Peninsula, Geophys. Res. Lett., 42, 2934-2942, doi:10.1002/2015GL063796, 2015.

Liu, X., Patsavas, M. C., and Byrne, R. H.: Purification and Characterization of meta-Cresol Purple for Spectrophotometric Seawater pH Measurements, Environ. Sci. Technol., 45, 4862-4868, doi:10.1021/es200665d, 2011.

Lueker, T. J., Dickson, A. G., and Keeling, C. D.: Ocean $p \mathrm{CO}_{2}$ calculated from dissolved inorganic carbon, alkalinity, and equations for $\mathrm{K} 1$ and $\mathrm{K} 2$ : validation based on laboratory measurements of $\mathrm{CO}_{2}$ in gas and seawater at equilibrium, Mar. Chem., 70, 105-119, 2000.

Moore, R. M., Lowings, M. G., and Tan, F. C.: Geochemical profiles in the Central Arctic Ocean: Their relation to freezing and shallow circulation, J. Geophys. Res., 88, 2667-2674, 1983.

Mucci, A.: The solubility of calcite and aragonite in seawater at various salinities, temperatures, and one atmospheric pressure, Am. J. Sci., 283, 781-799, 1983.

Orr, J. C., Fabry, V. J., Aumont, O., Bopp, L., Doney, S. C., Feely, R. A., Gnanadesikan, A., Gruber, N., Ishida, A., Joos, F., Key, R. M., Lindsay, K., Maier-Reimer, E., Matear, R., Monfray, P., Mouchet, A., Najjar, R. G., Plattner, G.-K., Rodgers, K. B., Sabine, C. L., Sarmiento, J. L., Schlitzer, R., Slater, R. D., Totterdell, I. J., Weirig, M.-F., Yamanaka, Y., and Yoo, A.: Anthropogenic ocean acidification over the twenty-first century and its impact on calcifying organisms, Nature, 437, 681-686, doi:10.1038/nature04095, 2005.

Pipko, I. I., Semiletov, I. P., Tishchenko, P. Ya., Pugach, S. P., and Christensen, J. P.: Carbonate chemistry dynamics in Bering Strait and the Chukchi Sea, Prog. Oceanogr., 55, 77-94, 2002.

Pipko, I. I., Semiletov, I. P., Pugach, S. P., Wåhlström, I., and Anderson, L. G.: Interannual variability of air-sea $\mathrm{CO}_{2}$ fluxes and carbon system in the East Siberian Sea, Biogeosciences, 8, 19872007, doi:10.5194/bg-8-1987-2011, 2011.

Proshutinsky, A., Krishfield, R., Timmermans, M.-L., Toole, J., Carmack, E., McLaughlin, F., Williams, W. J., Zimmermann, S., Itoh, M., and Shimada, K.: Beaufort Gyre freshwater reservoir: State and variability from observations, J. Geophys. Res., 114, C00A10, doi:10.1029/2008JC005104, 2009.

Redfield, A. C., Ketchum, B. G. H., and Richards, F. A.: The influence of organisms on the composition of sea-water, in: The Sea: Ideas and Observations on the Progress in the Study of the Seas, Vol. 2, edited by: Hill, M. N., 26-77, Interscience, New York, 1963.

Riley, J. P. and Tongudai, M.: The major cation/chlorinity ratios in sea water, Chem. Geol., 2, 263-269, 1967. 
Rudels, B., Jones, E. P., Anderson L. G., and Kattner, G.: On the intermediate depth waters of the Arctic Ocean, in: The Polar Oceans and Their Role in Shaping the Global Environment, edited by: Johannessen, O. M., Muench, R. D., and Overland, J. E., 33-46, American Geophysical Union, Washington, D.C., 1994.

Schlosser, P., Bauch, D., Fairbanks, R., and Bonisch, G.: Arctic river runoff: Mean residence time on the shelves and in the halocline, Deep-Sea Res. Pt. I, 41, 1053-1068, doi:10.1016/09670637(94)90018-3, 1994

Semiletov, I., Pipko, I. I., Repina, I. A., and Shakhova, N.: Carbonate dynamics and carbon dioxide fluxes across the atmosphereice-water interfaces in the Arctic Ocean Pacific sector of the Arctic, J. Mar. Syst., 66, 204-226, 2007.

Semiletov, I., Pipko, I., Gustafsson, Ö., Anderson, L. G., Sergienko, V., Pugach, S., Dudarev, O., Charkin, A., Gukov, A., Bröder, L., Andersson, A., Spivak, E., and Shakhova, N.: Acidification of East Siberian Arctic Shelf waters through addition of freshwater and terrestrial carbon, Nat. Geosci., 9, 361-365, doi:10.1038/ngeo2695, 2016

Semiletov, I. P., Savelieva, N. I., Weller, G. E., Pipko, I. I., Pugach, S. P., Gukov, A. Yu., and Vasilevskaya, L. N.: The dispersion of Siberian river flows into coastal waters: meteorological, hydrological and hydrochemical aspects, in: The Freshwater Budget of the Arctic Ocean, edited by: Lewis, E. L., 323-366, Kluwer Academic Publishers, Dordrecht, NATO Meeting/NATO ASI Series, 2000.

Shakhova, N., Semiletov, I., Sergienko, V., Lobkovsky, L., Yusupov, V., Salyuk, A., Salomatin, A., Chernykh, D., Kosmach, D., Panteleev, G., Nicolsky, D., Samarkin, V., Joye, S., Charkin, A., Dudarev, O., Meluzov, A., and Gustafsson, Ö.: The East Siberian Arctic Shelf: Towards further assessment of permafrost-related methane fluxes and role of sea ice, Philos. T. R. Soc. A, 373, 20140451, doi:10.1098/rsta.2014.0451, 2015.
Tesi, T., Semiletov, I., Hugelius, G., Dudarev, O., Kuhry, P., and Gustafsson, O.: Composition and fate of terrigenous organic matter along the Arctic land-ocean continuum in East Siberia: Insights from biomarkers and carbon isotopes, Geochim. Cosmochim. Ac., 133, 235-256, 2014.

Ulfsbo, A., Cassar, N., Korhonen, M., van Heuven, S., Hoppema, M., and Anderson, L. G.: Late summer net community production in the central Arctic Ocean using multiple approaches, Global Biogeochem. Cy., 28, 1129-1148, doi:10.1002/2014GB004833, 2014.

van Heuven, S., Pierrot, D., Rae, J. W. B., Lewis, E., and Wallace, D. W. R.: MATLAB Program Developed for $\mathrm{CO}_{2}$ System Calculations, ORNL/CDIAC-105b, Carbon Dioxide Information Analysis Center, Oak Ridge National Laboratory, US Department of Energy, Oak Ridge, Tennessee, doi:10.3334/CDIAC/otg.CO2SYS_MATLAB_v1.1, 2011.

Vonk, J. E., Semiletov, I. P., Dudarev, O. V., Eglington, T. I., Andersson, A., Shakhova, N., Charkin, A., Heim, B., and Gustafsson, O.: Preferential burial of permafrost-derived organic carbon in Siberian-Arctic shelf waters, J. Geophys. Res., 119, 8410-8421, doi:10.1002/2014JC010261, 2014.

Yamamoto-Kawai, M., Mclaughlin, F. A., Carmack, E. C., Nishino, S., and Shimada, K.: Aragonite undersaturation in the Arctic Ocean: effects of ocean acidification and sea ice melt, Science, 326, 1098-1100, doi:10.1126/science.1174190, 2009. 